\title{
DIRECT MEASUREMENT OF MERCURY REACTIONS IN COAL POWER PLANT PLUMES
}

Technical Progress Report

for the period September 18, 2004 through March 17, 2005.

Prepared for:

AAD Document Control

U.S. Department of Energy

National Energy Technology Laboratory

PO Box 10940, MS 921-107

Pittsburgh, PA 15236-0940

DOE Award DE-FC26-03NT41724

Performance Monitor: William Aljoe

Prepared by

Leonard Levin

Electric Power Research Institute

3420 Hillview Ave. Palo Alto, California 94304

June 2006 


\section{DISCLAIMER}

This report was prepared as an account of work sponsored by an agency of the United States Government. Neither the United States Government nor any agency thereof, nor any of their employees, makes any warranty, express or implied, or assumes any legal liability or responsibility for the accuracy, completeness, or usefulness of any information, apparatus, product, or process disclosed, or represents that its use would not infringe privately owned rights. Reference herein to any specific commercial product, process, or service by trade name, trademark, manufacturer, or otherwise does not necessarily constitute or imply its endorsement, recommendation, or favoring by the United States Government or any agency thereof. The views and opinions of authors expressed herein do not necessarily state or reflect those of the United States Government or any agency thereof.

\section{ACKNOWLEDGMENT}

This report was prepared with the support of the U.S. Department of Energy (DOE) National Energy Technology Laboratory Award No. DE-FC26-03NT41724. Any opinions, findings, conclusions, or recommendations expressed herein are those of the author(s) and do not necessarily reflect the views of DOE. 


\title{
DIRECT MEASUREMENT OF MERCURY REACTIONS IN COAL POWER PLANT PLUMES
}

\begin{abstract}
This project was awarded under U.S. Department of Energy (DOE) National Energy Technology Laboratory (NETL) Program Solicitation DE-PS26-02NT41422 and specifically addresses Program Area of Interest: \#5 - Environmental and Water Resources. The project team includes the Electric Power Research Institute (EPRI) as the contractor and the University of North Dakota Energy \& Environmental Research Center (EERC) and Frontier Geosciences as subcontractors. Wisconsin Energies and its Pleasant Prairie Power Plant acted as host for the field-testing portion of the research.

The project is aimed at clarifying the role, rates, and end results of chemical transformations that may occur to mercury that has been emitted from elevated stacks of coal-fired electric power plants. Mercury emitted from power plants emerges in either its elemental, divalent, or particulate-bound form. Deposition of the divalent form is more likely to occur closer to the source than that of the other two forms, due to its solubility in water. Thus, if chemical transformations occur in the stack emissions plume, measurements in the stack may mischaracterize the fate of the material. Initial field and pilot plant measurements have shown significant and rapid chemical reduction of divalent to elemental mercury may occur in these plumes.
\end{abstract}

Mercury models currently assume that the chemical form of mercury occurring in stacks is the same as that which enters the free atmosphere, with no alteration occurring in the emissions plume. Recent data indicate otherwise, but need to be evaluated at full operating scale under field conditions.

Prestbo and others have demonstrated the likelihood of significant mercury chemical reactions occurring in power plant plumes (Prestbo et al., 1999; MDNR-PPRP, 2000; EERC, 2001). This experiment will thus increase our understanding of mercury atmospheric chemistry, allowing informed decisions regarding source attribution.

The experiment was carried out during the period August 22-September 5, 2003. The experimental site was the Pleasant Prairie Power Plant in Pleasant Prairie, Wisconsin, just west of Kenosha. The experiment involved using an aircraft to capture emissions and document chemistry changes in the plume. While using the airplane for sampling, supplemental fast-response sensors for NOx, connected to data loggers, were used to gauge entry and exit times and transect intervals through plume emissions material. The Frontier Geosciences Static Plume Dilution Chamber (SPDC) was employed simultaneously adjacent to the stack to correlate its findings with the aircraft sampling, as well as providing evaluation of the SPDC as a rapid, less costly sampler for mercury chemistry. A complementary stack plume method, the Dynamic Plume Dilution (DPD) was used in the latter portion of the experiment to measure mercury speciation to observe any mercury reduction reaction with respect to both the 
reaction time (5 to 30 seconds) and dilution ratio. In addition, stack sampling using the "Ontario Hydro" wet chemistry method and continuous mercury monitors (CMM) were used to establish the baseline chemistry in the stack. Comparisons among stack, SPDC, DPD and aircraft measurements allow establishment of whether significant chemical changes to mercury occur in the plume, and of the verisimilitude of the SPDC and DPD methods.

This progress report summarizes activities during a period of results review from the stack/aircraft subcontractor, a draft progress report from the stack/aircraft subcontractor, attempts to elicit reports or data summaries from the plume chamber subcontractor, and preparation and presentation of preliminary results to technical and oversight meetings. 
TABLE OF CONTENTS

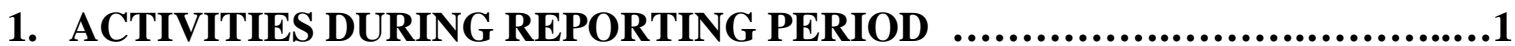




\section{DIRECT MEASUREMENT OF MERCURY REACTIONS IN COAL POWER PLANT PLUMES}

\section{1) ACTIVITIES DURING THE REPORTING PERIOD}

Reports

Subcontractor University of North Dakota Energy and Environmental Research Center (UNDEERC) provided a draft final report to EPRI on its portion of the project. UNDEERC was responsible for in-plant measurements and aircraft operations during the Pleasant Prairie plume chemistry project. The report provided raw data, data analysis and interpretation, and synthesis on measurements of coal content of mercury and chlorine, plant operations during the experimental period, and in-plant, in-stack, and stack exit measurements of mercury speciation, fluxes, and co-constituents. Aircraft operations were described, including: instrumentation and equipment selection, operation, and interaction; instrument calibration, ground and air checkout, and data logging; aircraft flight tracks on days of air measurements; instrument raw and processed data (conversion to ground level datum for valid data comparisons); and coordination among ground, in-plant, and air measurements.

\section{Papers and Presentations}

Principal Investigator Leonard Levin presented summary results and interpretation of results for source-receptor relationships to conferences, including:

- Edison Electric Institute Legal Committee, Boca Raton, FL, October 2004

- State of Indiana Department of Environmental Management Mercury Hearing, Vincennes, IN, December 2004

- State of Pennsylvania Mercury Workshop Invited Speaker, Harrisburg, PA, November 2004

- State of Georgia Mercury Workshop, Atlanta, October 2004

- STAPPA-ALAPCO Executive Director and Headquarters Staff, Washington, D.C., November 2004

\section{Subcontractor Report}

Repeated attempts by EPRI to reach and have response from Subcontractor Frontier Geosciences (FG) were carried out through late 2004 and early 2005. In early March 2005, a "Quick Summary" data table was delivered by FG to EPRI, along with the following comment:

Here is a quick look at the bottom line for the SPDC results. We observed NO conversion of $\mathrm{Hg}$ (II) to $\mathrm{Hg}^{\wedge} 0$. Our mass balances are similar to previous studies and are acceptable. The two red squares highlight this conclusion in two different ways. The upper red square shows the elemental mercury results - which are the most solid measurement we make. The expected and the measured are nearly equal - thus no conversion.

We'll need to make a list of why the airplane and SPDC results differ.

The Quick Summary table is attached as Appendix A. 


\section{2) APPENDIX A}

\section{PROJECT PRESENTATION AT 2004 MEGASYMPOSIUM}

Quick Summary Data Table, Frontier Geosciences Static Plume Dilution Chamber Experiment at Pleasant Prairie Power Plant, September 2003

\begin{tabular}{|c|c|c|c|c|c|c|c|}
\hline \multicolumn{8}{|c|}{ Pleasant Prairie Power Plant (P4) SPDC Data Summary } \\
\hline & Run ID & 0828-S1 & 0829-S2 & 0830-S3 & 0831-S4 & Mean & Mean \% \\
\hline Conditions, Files, Temp. & Units & & & & & & \\
\hline Input to SPDC & $\mathrm{ng}$ & - & 14.16 & 20.36 & 45.23 & 26.6 & $95 \%$ \\
\hline SPDC Background $^{\star \star}$ & ng & 1.52 & 2.01 & 1.00 & 1.06 & 1.4 & $4.9 \%$ \\
\hline Background $\quad \mathrm{Hg}^{0}$ & $\mathrm{ng} / \mathrm{m}^{3}$ & 2.64 & 3.50 & 1.75 & 1.84 & 2.4 & \\
\hline Expected Min. $\quad \mathrm{Hg}^{0}$ & $\mathrm{ng} / \mathrm{m}^{3}$ & 2.67 & 22.18 & 30.79 & 53.39 & 35.5 & \\
\hline Observed $\quad \mathrm{Hg}^{0}$ & $\mathrm{ng} / \mathrm{m}^{3}$ & 4.21 & 21.17 & 28.62 & 45.40 & 31.7 & \\
\hline Observed \% $\quad \mathrm{Hg}^{0}$ & $\%$ & $158 \%$ & $95 \%$ & $93 \%$ & $85 \%$ & $89 \%$ & \\
\hline Measured SPDC Gas Phase & $\mathrm{ng}$ & 1.74 & 10.67 & 15.30 & 23.35 & 16.44 & $68 \%$ \\
\hline Measured SPDC Rinse & $\mathrm{ng}$ & - & 9.89 & 4.12 & 9.68 & 7.9 & $32 \%$ \\
\hline Measured Total Hg in SPDC & $\mathrm{ng}$ & - & 20.56 & 19.42 & 33.03 & 24.3 & \\
\hline Expected Total Hg in SPDC & $\mathrm{ng}$ & - & 16.18 & 21.37 & 46.29 & 27.9 & \\
\hline Measured/Expected \% & & - & $127 \%$ & $91 \%$ & $71 \%$ & $96 \%$ & $28.3 \%$ \\
\hline \multicolumn{8}{|l|}{ with FMSS only } \\
\hline \multicolumn{8}{|l|}{ Calcultions at $\mathrm{T}=2.5$ minutes } \\
\hline Hg0 Expected & $\mathrm{ng} / \mathrm{m}^{3}$ & 2.67 & 22.18 & 30.79 & 53.39 & 42.09 & \\
\hline Hg0 Measured & $\mathrm{ng} / \mathrm{m}^{3}$ & 4.21 & 21.17 & 28.62 & 45.40 & 37.01 & \\
\hline $\mathrm{HgO}$ Net & $\mathrm{ng} / \mathrm{m} 3$ & 1.54 & -1.01 & -2.17 & -7.99 & -5.08 & $-12 \%$ \\
\hline & $\mathrm{ng}$ & 0.77 & -0.51 & -1.09 & -4.00 & -2.54 & \\
\hline$\underline{\mathrm{Hg}(\mathrm{II}) \text { input }}$ & $\mathrm{ng}$ & - & 4.8 & 5.8 & 19.5 & 12.65 & \\
\hline $\mathrm{Hg}(\mathrm{II})$ to $\mathrm{HgO}$ conversion & $\%$ & - & $-10 \%$ & $-19 \%$ & $-21 \%$ & -0.20 & $5.3 \%$ \\
\hline
\end{tabular}

